\title{
Workload analysis for Sanding Small Grand Piano Department in Manufacturing company
}

\author{
Amarria Dila Sari ${ }^{1, a}$, Ahmad Azhar Basyir ${ }^{1, b}$, M.Ragil Suryoputro ${ }^{1, c}$ \\ ${ }^{1}$ Industrial Engineering Deparment, Faculty of Industrial Technology, Islamic University of Indonesia, Jl. Kaliurang km 14.5, Yogyakarta \\ Indonesia
}

\begin{abstract}
The production process is one of the main activities of manufacturing companies that need their continuous improvement and continuously. There are several factors that affect productivity, such as job stress and workload. The workload is shared with uneven to make the work environment uncomfortable. The production data in April 2017 explaining that the sanding small grand piano average produces for 20 units piano/day, with a production target of 21 units piano/day production target has not been achieved. The lack of achievement of these targets due to the difference between the expected level of ability with the capacity level. In this study focused to determine the operator workload on sanding small grand piano is included in the painting section. The workload is calculated using the method of Full-Time Equivalent (FTE). The results showed that the operators have overloaded with FTE scores of both $1.33,1.35$ and 1.34 While the operators have an underload workload with a value of FTE 0.94. 0.64, 0.72. Therefore, Kaizen activity such as balancing jobdesk and modification stopper were applied to reduce the waste. Workload after kaizen plan has decreased each 0.02 FTE with change of work element, each operator has a uniform workload with an average FTE value of 1.13 (underload).
\end{abstract}

\section{Introduction}

Manpower planning is one of the problems for the company, among others related to the workload analysis is not balanced between the number of workload and the amount of labour [1]. Workload is a management technique systematically performed to obtain information about the effectiveness and efficiency of the organization based on the work volume [2]. Full-time Equivalent (FTE) is one of the tools used to measure the workload, by comparing the time spent in completing various jobs on the effective working time, as well as simplifying the work measurement by changing hours of workload to the number of people required to complete a specific job [3].

Several preliminary studies related workload with various methods including, the study of mental workload using NASA-Task Load Index (TLX) for industrial employees in manufacturing company [4], [5]. Study about physical workload for laundy worker using cardio vascular load method have also been analyzed [6]. Research related workload using workload indicators of staffing need (WISN) in Namibia [7]. Study related workload analysis using Full-time Equivalent has been carried out at foundry SME [8]. Moreover, research that concerned to analyse workload measurement or staffing need has been conducted on mining industry [9]. Research about workload measurement using worksampling and task per job has been carried out at service company [10]
This research was conducted on manufacturing company engaged in the assembly of non-traditional instruments with piano, electone, pianica, organ, and others. The resulting products include Upright Piano (UP) and Grand Piano (GP). This study is focused on knowing the workload of operators on the sanding small grand piano which is included in the painting division. April 2017 production data explains that sanding small grand pianos produce an average of 20 pianos / day, with a production target of 21 units of piano / day, the production target cannot be achieved yet. The lack of achievement of the target is due to the difference between the level of ability expected with the level of capacity owned.

This study aims to find out the operational workload of sanding small grand piano operators with full-time equivalent method based on kaizen improvement so that it can be used as input for the company to improve the performance of existing human resources. Kaizen approach is an ongoing process to reduce waste, increase productivity, improve quality, and utilize existing resource utilization [11]

\section{Theory}

\subsection{Human Resourches Management}

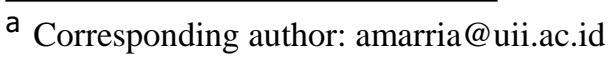


Human resource management is a strategic area of an organization [12]. Human resource management is the process of handling problems on various aspects ranging from employees, employees, labourers, managers, to other workforce to support organizational activities in order to achieve company goals that have been set [13]

\subsection{Workload Analysis}

The workload is the calculation and comparison between the needs of human resources or capacity required and the real capability of the human [14]. Workload is importance factor in determining human resource management policy in a system, such as personnel need planning [15].

\subsection{Kaizen}

Kaizen goal is a better product (improving quality), cheaper (lowering costs), safer (increased safety), faster (fix lead time), and more easily (increasing productivity) [16] . The most important element in kaizen is aware to Muda. Muda is some phenomena and effects that do not increase the value added.

\section{Methods}

\subsection{Research Subject}

This study was conducted on a sanding small grand piano division. Criteria subject in this research include male / female worker in sanding small grand piano, productive age workers range from 18 years to 45 years, workers with a minimum of one year's work experience, workers willing to be respondents.

\subsection{Research Procedure}

Research procedures were divided into the following phases:

a. Observation

Observations are made through observations in the field, as well as interviews with experts in the company.

b. Determine the work unit and employees who will carry out workload analysis.

c. Determine the effective working time

d. Effective working time is divided into effective working hours and effective working days. The effective working hours are hours in a day reduced allowance. While, effective working days are determined by:

1. Working days

2. Annual leave

3. Education and training

4. National libraries

\section{Absence of work}

6. Working hours

e. Allowance

Set up a standard allowance with the aim to determine the factors of worker / employee allowance which includes the type of activity and time requirements in completing a task / work that is not related to the main activity, such as allowance for personal needs, work environment.

f. Calculate the standard time

The stage of calculating the standard time starts with processing the cycle time that has been obtained and calculating the rating factor size for each working element. Then, the cycle time will be multiplied by the rating factor to calculate normal time. The next stage of normal time will be added with allowance for each operator, according to the elements of the job.

g. Calculate the workload

At this stage, the workload is calculated using the Full-Time Equivalent (FTE) method. The FTE value is useful for knowing the workload that is obtained by the operator. FTE value calculation itself use a standard time that takes into account daily production, total working time, and effective working time. In this study, the calculation was carried out in March 2017 May 2017 while June 2017 was used as a recommendation from this study. The implication of FTE value is divided into three types : overload, normal, and underload. Based on the workload analysis guidance, the total FTE index value above 1.28 is considered overload, between 1 to 1.28 is considered normal whereas if the FTE index value is between 0 to 0.99 considered underload or workload is still less than the maximum [17].

\section{Results and Discussion}

Respondents in this study were 6 operators, 3 male and 3 female operators, aged between 21-35 years. Company hours are from 07.00 to 16.00 everyday except for Saturdays and Sundays which are holidays. Operator 1 and operator 2 work on a belt sander machine that can only be done by male operators. Operator 3, operator 4, and operator 5 work on the hand sanding section. Operator 6 also worked on the hand sanding section but was sent to the Top Stick Long and Top Stick Short cabinets

Effective working hours / month is a multiplication of effective working days (no days off) multiplied by working hours / days. While the total effective working hours is the multiplication of working hours / month multiplied by the average effectiveness factor. The effectiveness factor is a factor involving the aspect of workers' allowance. The average allowance of all operators is $21 \%$ so that the average effectiveness factor is $79 \%(1-21 \%)$.

Allowance is the adjustment done to the normal time to obtain the standard time for the purpose to recover the lost time due to personal needs, fatigue, and unavoidable delays. 
The effective working time of March 2017 to June 2017 is shown by Table 1 below.

Table 1.Effective Working Time

\begin{tabular}{|l|c|c|c|c|c|}
\hline \multicolumn{1}{|c|}{ Description } & March & April & May & June & Unit \\
\hline $\begin{array}{l}\text { Work } \\
\text { hour/month }\end{array}$ & 22 & 19 & 21 & 15 & Day \\
\hline Work hour/day & 8 & 8 & 8 & 8 & Hour \\
\hline $\begin{array}{l}\text { Work hour/month } \\
\text { hour }\end{array}$ & 176 & 152 & 168 & 120 & Hour \\
\hline $\begin{array}{l}\text { Effectiveness } \\
\text { Factor }\end{array}$ & $79 \%$ & $79 \%$ & $79 \%$ & $79 \%$ & $\%$ \\
\hline $\begin{array}{l}\text { Total effective } \\
\text { working hour }\end{array}$ & 139 & 120 & 132 & 94 & $\begin{array}{c}\text { Hr/Mo } \\
\text { nth }\end{array}$ \\
\hline
\end{tabular}

\subsection{Workload Analysis}

The workload on sanding small grand piano for March 2017 - May 2017 is uneven due to the presence of operators with underload and overload workload. The second operator has an overload workload in April 2017 and May 2017 with an FTE of 1.33. For the sixth operator also has an overload workload in April 2017 and May 2017 with FTE values of 1.35 and 1.34 respectively. While the fourth operator has an underload workload in March 2017 with a value of FTE 0.94. And the fifth operator has an underload workload for March 2017 of 0.64 in April 2017 of 0.72 and May 2017 of 0.72 , can be seen in the Figure 1-3.

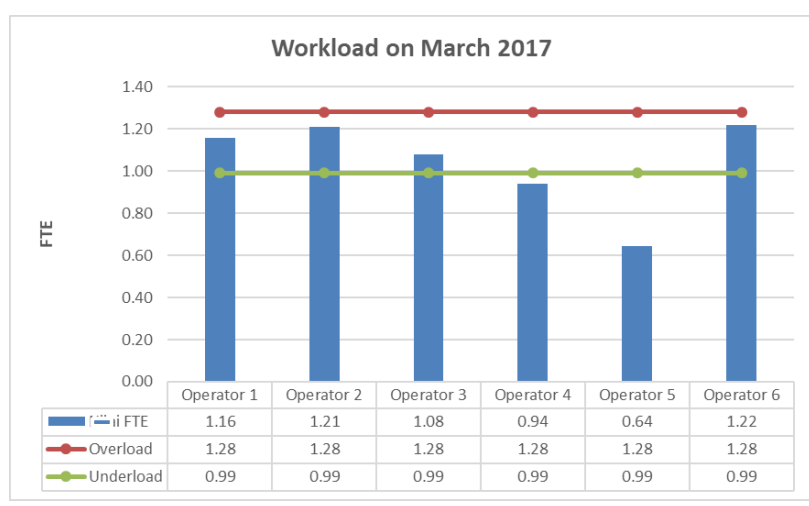

Figure 1. Workload on March 2017

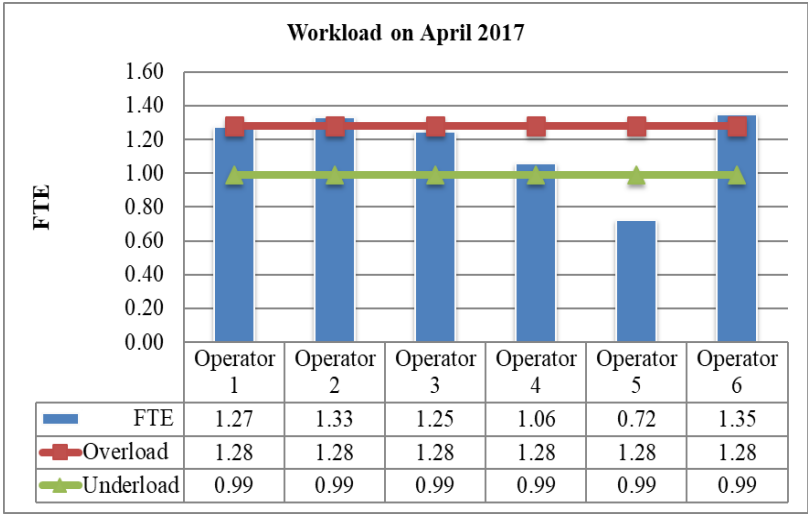

Figure 2. Workload on April 2017

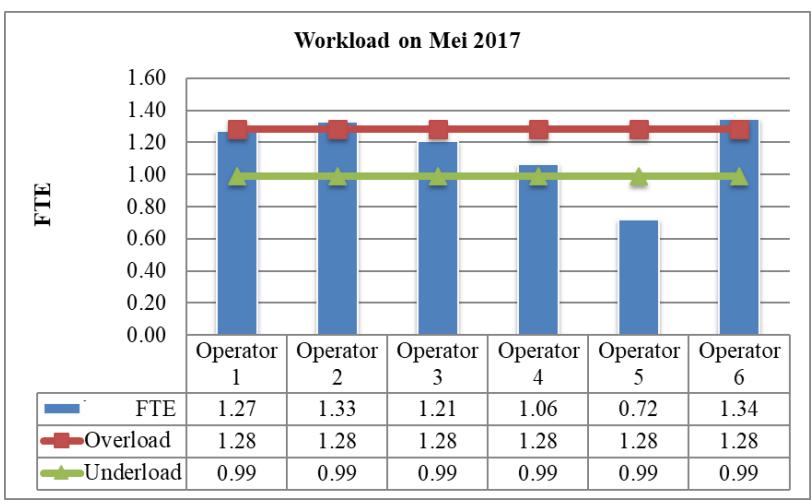

Figure 3. Workload on Mei 2017

\subsection{Workload Calculations After Kaizen Plan}

The kaizen plan on sanding small grand piano division by eliminating or combining work processes is useful to lower the operator's workload. Therefore, the workload for the operator becomes reduced. Kaizen is an ongoing process that can reduce waste, increase productivity, improve quality, and utilize existing resource utilization [10]. Kaizen has several concepts that can be used by companies to make improvements, one of them $3 \mathrm{M}$ or called Muda, Mura, and Mura. Muda is an activity that does not add value to the product, mura is an uneven process, and muri is an excessive worker burden [18]. In the present study there are several kaizen plans that are expected to decrease the workload of sanding small grand piano operators. The following comparison operator workload before and after kaizen plan in Figure 4. 


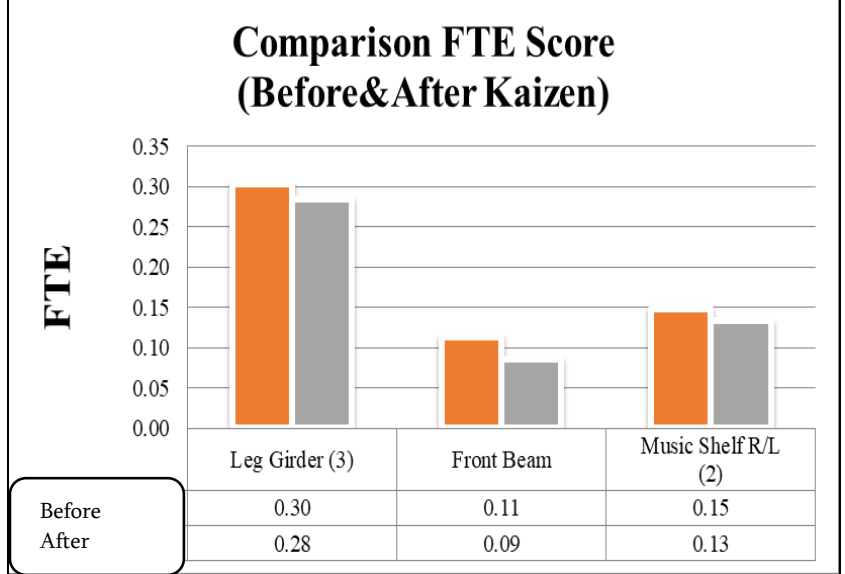

Figure 4. Comparison FTE Score (Before\&After Kaizen)

The kaizen plan is undertaken for improvement of uneven workload measurement results. [1] activity carried out includes the incorporation of work elements on the belt sander \# 500 cabinet leg girder ebony polish model with FTE value from 0.30 to 0.28 (Figure 4).

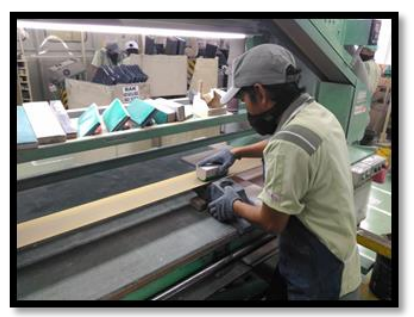

Figure 5. Kaizen Leg Girder

Second kaizen activity with stopper addition for belt sander element \# 500 front beam cabinet polish ebony (PE) model with FTE value down from 0.11 to 0.09 (Figure 5).

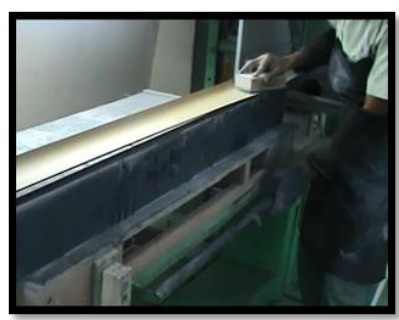

Figure 6. Kaizen Front Beam

While the value of FTE on the element belt sander \# 500 cabinet music shelf polish model ebony (PE) fell from 0.15 to 0.13 with stopper modifications (Figure 6).

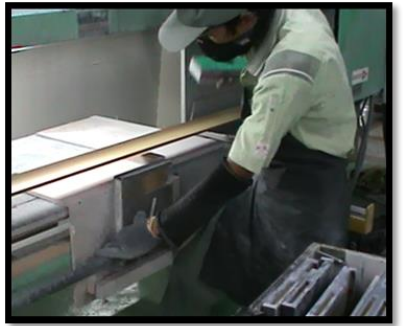

Figure 7.Kaizen Music Shelf

\section{Conclusion}

Based on the research, could be concluded that all operator was categorized on FTE were not balanced. The operators have overloaded with FTE scores of both 1.33, 1.35 and 1.34 While the operators have an underload workload with a value of FTE 0.94. 0.64, 0.72. Therefore, Kaizen activity such as balancing jobdesk and modification stopper were applied to reduce the waste. Workload after kaizen plan has decreased each 0.02 FTE with change of work element, each operator has a uniform workload with an average FTE value of 1.13 (underload). Further research should be done by increasing the number of samples to further strengthen the research.

\section{References}

[1] H. Purnomo , "Workload Analysis for Determining the Number of Employees at Banking Companies," Gema, p. 50, 2015.

[2] J. Hurd, FTE for Definition.Calculations,Examples And System Usage Information For HRMS and GL Budget Purpuses, Colorado, 2004.

[3] Depkeu, Pedoman Pelaksanaan Analisis Beban kerja di Lingkungan Departemen Keuangan. RI, 2006.

[4] Puspawardhani, "Mental Workload Analysis Using NASA-TLX Method Between Various Level of Work in Plastic Injection Division of Manufacturing Company," in In Advances in Safety Management and Human Factors, Orlando, 2016

[5] T. Sealetsa, "Ergonomics issues among sewing machine operators in the textile manufacturing industry in Botswana," Work, vol. 38, no. 3, pp. 279-289, 2011.

[6] Sari, A.D., Suryoputro, M.R., Pramaningtyas, M.D., Putra, P.S. and Maulidyawati, S.B.,," in IOP Conference Series: Materials Science and Engineering, Yogyakarta, 2016.

[7] P. Mc QUide, R. Kolehmainen-Aitken, R.-L. and N. Foster, "McQuide, P. A., Kolehmainen-Aitken, R.L., \& Forster, N. (2013). Applying the workload indicators of staffing need (WISN) method in Namibia: challenges and implications for human resources for health policy," 2013.

[8] A. Sari, F. Hardiansal and M. Suryoputro, 
Workload assessment on foundry SME to enhance productivity using full-time equivalent," in MATEC Web of Conferences, Yogyakarta, Indonesia, 2017.

[9] Hutagalung, R., and Gustomo, A., Workload Analysis for Planning Needs of Personnels in the Corporate Administration Unit PT Timah (Persero) TBK. The Indonesian Journal of Business Administration vol. 2, no. 19, 2290-2297, 2012

[10] A. Syamsul and Jasril, The Measurement Of Workload And Optimal Number Of Education Personnel Using Work Sampling And Task Per Job Methods (A Case Study At Pt X.) in IOP Web Conferences, 2017

[11] Bwemelo and Gordian, "Kaizen as a strategy for improving SSME's peformance: assessing its acceptability and feasibility in tanzania.," European journal of business and management, 2014.

[12] Ulrich, D. Human resource champion: the next agen for adding value and delivering result. harvard business school press. 1991

[13] Moekijat. Manajemen personalia dan sumber daya manusia. Yogyakarta: BFFE. 2008

[14] OrientPoint. FTE Analysis and Models, Retrived from : http://www.orientpoint.com/FTE.htm. 2014

[15] Niebel, B.W and Freivalds, A. Methods, Standards, and Work Design. John-Wiley \& Sons, New York.2002

[16] Liker, J. K.,. The Toyota Way. (Gina Gania \& Bob Sabran, Penerjemah). Jakarta: Erlangga.2004

[17] Dewi, U., \& Satya, A. Analisis kebutuhan tenaga kerja berdasarkan beban kerja karyawanpada PT PLN (Persero) distribusi Jakrta raya dan Tangerang bidang sumber daya manusia dan organisasi. 2012

[18] Imai, Masaaki. Gemba Kaizen: A commonsense approach to a continuous improvement strategy. New York: McGraw Hill, 2012. 